\title{
Commemoration as reconciliation: Indigenous history and Canada's heritage designation system
}

\section{CJ Pentland}

\section{Abstract:}

In September 2020, the Canadian federal government designated the residential school system as an event of national historic significance and two former residential school buildings as national historic sites. They joined over 2,150 other places, people, and events that have been certified as part of Canada's official historical narrative - the majority of which celebrate the nation's imperialist history and silence Indigenous peoples. However, public representations of historic injustices that honour victims have the power to disrupt laudatory versions of the past and foster reconciliation. This paper will examine the history of Canada's commemorative efforts and its effect on the nation's collective memory, before exploring how the heritage designation framework can be decolonized in a way that respects the needs and desires of Indigenous peoples.

\section{Keywords:}

commemoration, reconciliation, Indigenous history, Canadian heritage designations

DOI: $10.33137 /$ ijournal.v6i2.36456

(C) 2021, Pentland, C. Commemoration as reconciliation: Indigenous history and Canada's heritage designation system. This is an Open Access article distributed under CC-BY. (c) (i) 
Pentland, Commemoration as reconciliation: Indigenous history and Canada's heritage designation system

\section{Introduction}

In September 2020, the Canadian federal government designated the country's residential school system as an event of national historic significance, and two former residential school buildings as national historic sites (Stefanovich, 2020). These commemorations occurred five years after the Truth and Reconciliation Commission (TRC) published a report that summarized information gathered during six years of conversations with residential school Survivors. The practices of the government-sponsored system are best described by the TRC as "cultural genocide" (2015, p. 1), but the abuses that Indigenous children suffered while attending the schools remain relatively unknown by many non-Indigenous people. This chapter of history has been absent from the nation's 'official' historical narrative, as Canada's commemorative efforts have produced a celebratory settler story that largely ignores Indigenous history and heritage (Regan, 2010 , p. 75). However, Survivor-driven public representations of past wrongs and cultural trauma have the ability to disrupt laudatory versions of history and provide opportunities for education and dialogue (Regan, 2010, p. 73; TRC, 2015, p. 288). The TRC report concluded with 94 Calls to Action that redress the legacy of the residential school system and advance reconciliation efforts, and Call to Action \#79 calls for collaboration with Indigenous peoples in developing a reconciliation framework for heritage and commemoration (TRC, 2015, p. 292). This paper will explore the role that commemoration can play in reconciliation, first by assessing how Canada's 'official' commemorations have shaped Canadians' understanding of Indigenous peoples and their history, and then by examining the value of public displays that recognize Indigenous ways of knowing, multiple versions from the past, and the harms caused by colonial practices.

\section{Commemoration and the Canadian state}

With the September 2020 announcement from the federal government, Canada's residential school system, the Portage La Prairie Residential School in Manitoba, and the Shubenacadie Residential School in Nova Scotia joined over 2,150 other places, people, and events certified as being of national historic significance (Parks Canada, 2020). The Federal Heritage Designations are one of the main ways that the federal government strives to educate Canadians about the nation's history, as these commemorations have been officially recognized as important aspects of the country's past (Taylor 1983, p. 3). This process is overseen by the Historic Sites and Monuments Board of Canada (HSMBC), a government agency that works closely with Parks Canada and advises the federal government on subjects worthy of commemoration (Parks Canada, 2019). The board is comprised of one representative from each province and territory, in addition to represen- 
tatives from Library and Archives Canada, the Canadian Museum of History, and Parks Canada. Any Canadian can nominate a person, place, or event for designation, but the submission must meet select criteria (Parks Canada, 2018), and the HSMBC makes the final decisions as to what gets commemorated. Once approved, the HSMBC installs a plaque with a short description that informs the public about the subject's historical significance (Morgan, 2016, p. 112). As of 2019 there are 265 Indigenous designations, and 105 of the plaques include an Indigenous language (Parks Canada, 2019).

Prior to the HSMBC's creation in 1919, Canada paid little attention to preserving and promoting its national history. Early commemorative efforts were mainly led by regional historical groups that lobbied the government to preserve sites they deemed historic - particularly forts and military sites (Taylor, 1983, p. 4). These commemorations expressed a nationalism that had started to grow throughout the late nineteenth century, and the few that were recognized reflected an intention to memorialize historic individuals and teach cultural values to new citizens (Ricketts, 1996, p. 25). One such location that received formal recognition during this period was the Plains of Abraham battlegrounds in Quebec. Leading up to the 300-year anniversary of the 1608 'founding' of Quebec City by Samuel de Champlain, the government agreed to formally commemorate the site since they believed that it represented where the British and French gave birth to the Canadian nation. The plaque unveiling provided an early example of the imperialist historical narrative that the federal government wanted Canadians to know, as Governor General Earl Grey told the crowd that "it is from this inspiring standpoint of Canadian nationality that the proposal to celebrate the three hundredth birthday of Canada... should win the enthusiastic support of every patriotic Canadian" (Taylor, 1983, p. 5). The focus on Canada's nation-building experience was part of a wider educational effort to create a national memory of assimilationist intent (Ricketts, 1996, p. 24), and this framework has had a lasting impact on how Canadians perceive their country's history.

Following the First World War, the Canadian federal government established the HSMBC as a way to centralize their approach to commemoration and public history. They appointed male volunteers from historical organizations across Canada and asked them to recommend buildings and landmarks that had historical significance_-but Indigenous peoples were excluded from the process and non-British communities had limited input (Ricketts, 1996, p. 24). Yves Pelletier described the group as a "Victorian gentleman's club where decisions were made based on the recommendations of the board alone" (2006, p. 134), and as a whole they saw themselves as "an elite whose superior education made them responsible for the tutelage and instruction of Canadians, iJournal, Vol 6, No. 2, 
particularly youth and new immigrants" (Morgan, 2016, p. 114). One of the key figures during this period was national parks commissioner James B. Harkin, who said in 1914 that the designation system would both educate Canadians and "stimulate that patriotism which a knowledge of our history is bound to develop" (Harkin Papers, 1914, as citied in Taylor, 1983, p. 24). The relationship between commemoration and Canadian identity remains prevalent today, as national historic sites are said to "stretch the imagination, tug at the heartstrings, and touch the soul," and the "moving, memorable opportunities... give visitors a feel for where Canada has come from, where it is today, where it is going in the future" (Parks Canada, 2019). Yet while the designations have diversified over time to include historical injustices, the nation still fortifies its sense of identity when it recognizes and transcends its 'shameful' past (Ghaddar, 2016, p. 16). This framework allows the government to select certain events and ignore the broader damage caused by colonialism, and because of this, many Canadians have a lack of awareness about Indigenous peoples' contributions to Canada - which fuels racist attitudes and distrust. As stated by the TRC, history plays an important role in reconciliation, and Canadians must learn from the past in order to build for the future (TRC, 2015, p. 8).

The HSMBC's principles and criteria for designation have shifted over the past century, but the overall focus has promoted a settler historical narrative. Canada's early historic sites were meant to represent a nationalist endeavour that attempted to assimilate all citizens into a monocultural whole based on British values, and this meant presenting a version of history "intimately associated with colonial expansion bolstered by military force and leavened by the architectural legacy of the successful elites" (Ricketts, 1996, p. 24). At the board's first meeting, they adopted a framework that sorted proposed designations into one of five categories: pre-historic sites, Indian forts, French memorials, Loyalist landing places, and landmarks of immigration from the British Isles (HSMBC, 1919, as cited in Taylor, 1983, p. 9). The interwar period saw their scope expand to recognize Indigenous treaties and leaders as historically significant, but their scope remained limited; members rejected requests to recognize Canada's first synagogue and Vancouver Island's Black community from before British Columbia became a colony, and the commemoration of the "saving of the prairie buffalo" neglected the fact that colonial policies led to their depopulation in the first place (Morgan, 2016, p. 119; Olson, 2019). This settler narrative created a version of a shared past that hid the evidence of offences committed by the state against Indigenous peoples. In 'Archival Amnesty,' Tonia Sutherland (2017) highlights how archives in the United States that attempt to be 'neutral' intentionally turn away from documenting injustices against Black Americans. The HSMBC operates in a similar fashion, as their refusal to acknowledge the nation's hu- 
man rights abuses erases the events from the history books and raises questions of the adequacy of the Canadian historical record (Sutherland, 2017, p. 8). Recent designations such as the residential school system may attempt to fill these historical gaps, but to be effective, the commemorations must elevate human rights and social justice, rather than be places of oblivion that offer forgiveness to those who perpetrate crimes against vulnerable communities (Sutherland, 2017, p. 19).

The residential school designations suggest that the federal government has considered how official commemorations must move beyond celebratory, settler narratives. The July 31, 2020 press release that announced four new historic designations that recognize Black history in Canada - one of which was the 'Enslavement of African people in Canada' - states that the designations encourage Canadians "to acknowledge the struggles and conflict that have led [the country] to the Canada of today, and help [Canadians] build a more inclusive society for today and future generations" (Parks Canada, 2020). Additionally, it highlights the need for Canadians to learn about the "tragic and shameful periods" that are part of the country's collective past. Parks Canada's 'Framework for History and Commemoration' (2019) says that the HSMBC now focuses on the "experiences of everyday people and forces driving change such as industrialization and immigration" (p. 20), and Parks Canada's four main strategic priorities are the history of Indigenous peoples, environmental history, diversity, and Canada and the world (p. 24). However, considerable work is required to back up these words and demonstrate real social change. The TRC believes that reconciliation requires Canada's national heritage values and practices to undergo a paradigm shift (2015, p. 291), and participants at Parks Canada's 2018 gatherings on Indigenous cultural heritage spoke to how the current framework is "a colonial system that lacks recognition of the perspectives of Indigenous peoples" (Parks Canada, 2019, p. 13) - a statement backed up by the fact that fewer than 5\% of HSMBC plaques include an Indigenous language (Parks Canada, 2019). Further feedback showed that historic sites can be important venues for youth to learn Indigenous histories, but also that these sites currently tell colonial stories and a one-sided view of the past - meaning that these histories cannot be taught effectively unless Indigenous peoples are involved in the commemoration process (Parks Canada, 2019, p. 16).

In the rare instances that the HSMBC has recognized Indigenous history, the designations exemplify the subjective and interventionalist practice of commemoration. As a whole, Indigenous peoples are mostly depicted as either archeological subjects who no longer existed after the settlers arrived, or as individuals who supported Canada's colonial efforts (Cole, 2017, p. 2). The designation of Cut Knife Hill, a key site during the 1885 Northwest Rebellion, represents one such case. As shown by C.J. Taylor's research (1983), the HSMBC initially declined to recognize sites iJournal, Vol 6, No. 2, 
related to the rebellion due to differing opinions on whether or not they were "nationally significant,' and the board struggled to write an inscription for the plaque once approved in 1923. They eventually turned to William Otter - the man who led the government troops during the battle for his input, and he wrote his own description that referred to the Indigenous as 'rebels,' provided an incorrect motivation for his troops' raid, and falsely presented the government as victorious. While the board unanimously approved the text, the plaque's unveiling brought public backlash; members of the Poundmaker reserve objected that their losses were unaccounted for and that they were depicted as 'rebels' rather than fighting for their rights, and French-Canadians and the Métis highlighted the absence of French on the plaque. This scenario exemplifies how the Canadian nation state created a white settler mythology of their past that disavowed their military conquests and assimilationist policies (Ghaddar, 2016, p. 18), and how their settler logic erased Indigeneity by making it seem that Indigenous peoples disappeared during the settlement process (Razack, 2002; Smith, 2014, p. 218). As Canada's settler society grew throughout the twentieth century, Indigenous people were not only dispossessed of their land but also erased discursively from the country's history (Ghaddar, 2016, p. 19).

The HSMBC's commemorations as a whole have also contributed to a romanticized myth of the nation's past. Richard Slotkin writes that people invoke myths "as a means of deriving useable values from history... Its primary appeal is to ritualized emotions, established beliefs, habitual associations, memory, [and] nostalgia (1985, p. 19, as cited in Regan, 2010, p. 67), and Margaret MacMillan states that public forms of history typically serve as a comforting escape into a nostalgic romanticized past (2008, p. 30). In Canada, this means that myth shapes and reinforces a complimentary history of peacekeeping and a multiculturalism. The settler narratives that derive from these myths create perceptions of a pioneer spirit where explorers civilized new frontiers and settled empty lands, while simultaneously stereotyping Indigenous peoples as "noble savages, violent warriors, victims of progress, and more recently, as protestors, rich Indians and undeserving beneficiaries of race-based rights" (Regan, 2010, p. 68). The HSMBC can feed these narratives by omitting historical events that disturb the status quo, which reflects Geoffrey Hartman's concern that sometimes "the greatest danger to public memory is the official story" (1993, p. 242, as cited in Strong-Boag, 2009, p. 57, emphasis in the original). If reconciliation is to be achieved in Cana$\mathrm{da}$, the nation must expose the role that myth and stereotype play in conflict - both in the past and the present (Rice and Snyder, 2008, p. 54). 


\section{A decolonized commemorative framework}

Commemorations that recognize historical injustices and honour victims have the potential to disrupt Canada's laudatory historical narratives and challenge the public to confront its comfortable myths (Regan, 2010, p. 73). While the country's history has mainly been presented as a celebratory settler story, 'unofficial' commemorations from grassroots groups can challenge traditional frameworks that operate under the guise of neutrality and provide a space that gives a voice to multiple versions of the past, speaks hard truths, expresses contradictory emotions, heals wounds, and engenders hope (Regan, 2010, p. 82). The TRC (2015) recognizes that commemoration can play a role in Canada's reconciliation process, but the process must go beyond recognizing select 'shameful' events from the colonial past. In order to establish the mutually respectful relationship between Indigenous and non-Indigenous peoples that is needed for reconciliation, Canadians must embrace the unsettling process of decolonizing the federal heritage designation system and ensure that commemorations meet the needs and desires of Indigenous peoples (Tuck \& Yang, 2012).

Designating the residential schools as significant aspects of Canada's history is seen as a victory by many Survivors, and the National Centre for Truth and Reconciliation (NCTR) views it as an important step in responding to the TRC's calls to action (Kirkup, 2020; Stefanovich, 2020). Part of what makes the commemoration significant is that the NCTR and its Survivors circle co-developed the designations with the HSMBC and Parks Canada (Kirkup, 2020). The main focus of Call to Action \#79 is the need for the federal government to collaborate with Survivors, Indigenous organizations, and the arts community to develop a reconciliation framework for Canadian heritage and commemoration, and this involves revising polices and criteria for commemoration and including Indigenous representation on the HSMBC board (TRC, 2015, p. 291). These two actions are required to produce the structural changes that have been absent from past attempts to diversify Canada's commemorative process. Efforts by non-Indigenous peoples have largely treated decolonization as a metaphor, which reinforces pre-existing beliefs and gets in the way of creating meaningful relationships. Eve Tuck and K. Wayne Yang describe these tropes as a series of moves to innocence (Malwhinney, 1998) that "problematically attempt to reconcile settler guilt and complicity, and rescue settler futurity" (2012, p. 3), and represent a settler fantasy of an easy path to reconciliation. If Canada's heritage designation system is to account for Indigenous sovereignty, the framework must recognize Indigenous knowledge and abolish the assimilationist approach that places Indigenous theory and pedagogy into Western theoretical frameworks 
Pentland, Commemoration as reconciliation: Indigenous history and Canada's heritage designation system

(Grande, 2015).

Since commemorations related to the residential school system are sites that document historical injustices and cultural trauma, the public displays must respect Survivors' needs. The TRC developed a framework for commemoration in conjunction with the TRC Survivor Committee, and together they identified three elements that are considered essential to supporting long-term reconciliation: the projects must be Survivor-driven, create new connections that link Indigenous family and community memory to Canada's public memory and national history, and incorporate Indigenous oral history and memory (2015, p. 284). Following these principles, commemoration should invite dialogue about a contentious past and bear witness to the loss and suffering that Indigenous peoples have endured - but also acknowledge that the process of remembering can invoke contradictory feelings (2015, p. 283). Some Survivors and their families might not want their loss memorialized (Byrne, 2009, p. 241, as cited in Cooper-Bolam, 2018, p. 61), and others may want to protect their story from being appropriated by Canada's historical record (Ghaddar, 2016, p. 21). For example, Survivors and their families chose to ceremonially destroy the Alberni Indian Residential School in British Columbia, as the demolition served as both a political and healing action that reclaimed the site and returned power the communities it had been stolen from (Cooper-Bolam, 2018, p. 68). This approach aligns with the Feminist Manifesto-No (2019), a "declaration of refusal and commitment" whose guiding principles include a commitment to "acknowledge how historical systemic patterns of violence and exploitation produce differential vulnerabilities for communities." By situating the designation process within Indigenous ways of knowing, Canada can unsettle its colonial framework and ensure that the public displays do not reproduce the violence and trauma that they are meant to commemorate (Cowan \& Rault, 2018).

Public displays must also be connected with the present in order to contribute to reconciliation. Michel-Rolph Trouillot (2015) argues that commemorations cannot solely serve as a vehicle for transmitting knowledge, as they need to establish an ethical and authentic relationship to the past (p. 149). To do this, public history must reject the myth of "The Past as a fixed reality and the related view of knowledge as a fixed content (p. 147). Jesse Boiteau (2020) makes a similar argument, as he calls for deconstructing the colonial 'single authorship' framework that treats a historical record's subjects as passive bystanders - something that early designations did to Indigenous peoples. Building off this, Paulette Regan (2010) writes that displays of historical injustices must be linked to on-going racism and oppression in order to prevent colonial empathy, and this relationship is something the federal government appears to acknowledge in their July 2020 announcement of the four new designations that recognize Black history in Canada. The press 
release stated that Black Canadians continue to face "prejudice, inequalities, and systemic barriers to equal participation in society," and the write-up for the commemoration of 'The Enslavement of African People in Canada' concludes by saying that the roots of systemic racism can be traced back to the "many, complex legacies of enslavement" (Parks Canada, 2020). J.K. Olick (1999) writes that "commemoration is a way of claiming that the past has something to offer the present, be it a warning or a model" (as cited in Regan, 2010, p. 78), and for much of Canadian history, the nation's commemorations were a model for a society that left Indigenous peoples in the past. However, this past can be 'restoried' within the context of the present (Regan, 2010, p. 73), and the process does not have to be done through traditional frameworks.

Counter-monuments and 'unofficial' commemorations that bypass values-based heritage discourse can provide a way for Indigenous peoples to restory their history and create space for multiple versions of the past. Between 2011 and 2014, Indigenous community and reconciliation advocacy groups received 20 million dollars from Aboriginal Affairs and Northern Development Canada through the commemoration component of the Indian Residential Schools Settlement Agreement. With this money, the groups produced 144 commemorations that Trina Cooper-Bolam (2018) calls "counter-monuments" since the projects "inaugurated unique reclamative and healing commemorative forms and practices, unsetting conventional Canadian understandings of the monument" (p. 59). The projects ranged from virtual quilts, to cemetery restoration, to totem pole and canoe carving, which as a whole rejected Western modes of heritage commemoration and challenged Canada's public memory and national history (TRC, 2015, p. 283; Cooper-Bolam, 2018, p. 73). Cooper-Bolam's research on the 144 commemorations found that because they prioritized healing and community-based reconciliation over education, Survivors were actively honoured, the monuments were reinterpreted or culturally interpreted, and the monuments remained in the community $(2015$, p. 72 ). Once such public display is the Shingwauk Residential Schools Centre in Ontario (n.d.), which houses a Survivor-driven exhibition in a former residential school building. Reclaiming Shingwauk Hall embodies a concept of 'layer-making' where sites "initially constructed for a particular purpose ... take on additional significance through the use, change, or even removal of their tangible fabric" (Brace, 2014, p. 10, as cited in Cooper-Bolam, 2018, p. 69). The exhibition describes itself as an example of "the future of Indigenous driven, decolonized history practice, which embraces community authority" (n.d.), and can therefore serve as a model for Canada's new National Historic Sites that commemorate other former residential school buildings.

John Borrows (2014) argues that reconciliation is a nation-wide process that is the responsibility of all Canadians, and commemorations have the ability to contribute. Shingwauk presents iJournal, Vol 6, No. 2 , 
the building's 110-year history as a residential school within the larger context of colonialism, truth telling, and reconciliation in Canada (n.d.), and the Survivors' histories that it tells challenge the accounts of traditional historians who consider themselves neutral and objective "gatekeepers" of knowledge (Million, 2004, as cited in Regan, 2010, p. 75). Public history displays that avoid emotion produce a sanitized version of public history that feeds false innocence about the past (Regan, 2010, p. 76) and detracts from the possibility of meaningful discussion on true reconciliation (Alfred, 2005, p. 152). Borrows writes that all Canadians bear a responsibility to those who were harmed by colonial violence; the nation must admit its public and private faults and weaknesses, as "the recognition of responsibilities for the harms generated through residential schools is a step in the right direction in acknowledging this truth" (2014, p. 504). When commemorations produce an awareness of the past, acknowledge harm, atone for the causes, and provide action to change behaviour, they can assist Indigenous and non-Indigenous peoples as they establish and maintain the mutually respectful relationships that reconciliation requires (TRC. 2015, p. 6).

\section{Conclusion}

Throughout Canada's settler past, Indigenous peoples have been both victimized by colonialism and revictimized by whitestream history (Grande, 2015, p. 242). The nation's federal heritage designation system has mainly told colonial stories and created romanticized myths about the past, which has led to a lack of historical knowledge among Canadians and impeded the reconciliation process (TRC, 2015, p. 8). The September 2020 designations of the residential school system as a nationally historic event and two former residential school buildings as historic sites may answer part of Call to Action \#79 of the Truth and Reconciliation Commission, but Canada's commemorative framework must be decolonized in order to move beyond the country's settler narrative and account for Indigenous sovereignty and futurity (Tuck \& Yang, 2012). Simply acknowledging the past and exposing historic injustices does not build trust or reconciliation, but rather solidifies an entitled settler sense of self and provokes colonial empathy (Ghaddar, 2016, p. 20; Regan, 2010). Instead, when residential school Survivors lead the commemoration process, the public displays can both meet their needs and provide opportunities for ongoing public education and dialogue (TRC, 2015, p. 184). Frantz Fanon (1963) writes that "decolonization never takes place unnoticed" (p. 36), and when commemorations recognize Indigenous peoples and their histories in ways that respect their needs and desires, all Canadians can take notice and understand the truth about the nation's past. 
Pentland, Commemoration as reconciliation: Indigenous history and Canada's heritage designation system

\section{References}

Alfred, T. (2005). Wasa'se: indigenous pathways of action and freedom. Broadview Press. https://books-scholarsportal-info.myaccess.library.utoronto.ca/uri/ebooks/ebooks2/utpre ss/2013-08-26/1/9781442602182

Boiteau, J. (2020, October 8). Hidden voices: The plurality of provenance \& the deconstruction of the colonial truth. Faculty of Information. University of Toronto.

Borrows, J. (2014). Residential schools, respect, and responsibilities for past harms. The University of Toronto Law Journal, 64(4), 486-504. http://www.jstor.org/stable/24311938

Brace, A. (2014). Heritage alternatives at sites of trauma: Examples of the Indian Residential Schools of Canada [Unpublished master's thesis]. University of York.

Byrne, D. (2009). A critique of unfeeling heritage. In Smith, L. \& Akagawa, N. (Eds.), Intangible heritage (pp. 229-252). Routledge.

Cifor, M., Garcia, P., Cowan, T.L., Rault, J., Sutherland, T., Chan, A., Rode, J., Hoffmann, A.L., Salehi, N., Nakamura, L. (2019). Feminist Data Manifest-No. Retrieved from https://www.manifestno.com

Cole, R. (2017). Historic Sites and Monuments Board of Canada's representation of Indigenous history from 1945 to 1982. [Unpublished master's thesis]. University of Ottawa. http://parkscanadahistory.com/publications/hsmbc/cole-2017.pdf

Cooper-Bolam, T. (2018). On the call for a residential schools national monument. Journal of Canadian Studies/Revue d'études canadiennes, 52(1), 57-81. https://www.muse.jhu.edu/arti$\underline{\text { cle } / 703426}$

Cowan, T.L. \& Rault, J. (2018). Onlining queer acts: Digital research ethics and caring for risky archives. Women \& Performance: A Journal of Feminist Theory, 28(2), 121-142. https://doi-org. myaccess.library.utoronto.ca/10.1080/0740770X.2018.1473985

Fanon, F. (1963). The wretched of the earth. Grove Press.

Ghaddar, J. (2016). The Spectre in the Archive: Truth, Reconciliation, and Indigenous Archival Memory. Archivaria, 82, 3-26. https://www.muse.jhu.edu/article/687080.

Grande, S. (2015). Red pedagogy: Native American social and political thought. Rowman \& Littlefield.

Harkin Papers. (1914, March 20). Memorandum re: Dominion Parks, their value and ideals.

Hartman, G. H. (1993). Public memory and modern experience. The Yale Journal of Criticism, 6(2), 239-247. http://myaccess.library.utoronto.ca/login?qurl=https\%3A\%2F\%2Fwww.proquest.com $\% 2$ Fscholarly-journals $\% 2$ Fpublic-memory-modern-experience $\% 2 \mathrm{~F}$ docview $\% 2$ F $1300859672 \% 2 F s e-2 \% 3$ Faccountid\%3D14771.

Historic Sites and Monuments Board of Canada [HSMBC]. (1919, October). Minutes.

Kirkup, K. (2020, September 1). Residential school system to be recognized as matter of national historic significance. The Globe and Mail. Retrieved from https://www.theglobeandmail.com/politics/article-residential-school-system-to-be-recognized-as-matter-of-national/.

iJournal, Vol 6, No. 2, 
Pentland, Commemoration as reconciliation: Indigenous history and Canada's heritage designation system

Macmillan, M. (2008). The uses and abuses of history. Viking Canada.

Mawhinney, J. (1998). 'Giving up the ghost': Disrupting the (re)production of white privilege in anti-racist pedagogy and organizational change [Unpublished master's thesis]. University of Toronto. http://www.collectionscanada.gc.ca/obj/s4/f2/dsk2/tape15/PQDD 0008/MQ33991.pdf.

Million, D.L. (2004). Telling secrets: Sex, power and narrative in the rearticulation of Canadian residential school histories [PhD dissertation]. University of California, Berkeley.

Morgan, C. (2016). Commemorating Canada: history, heritage, and memory, 1850s-1990s. University of Toronto Press.

Olick, J. (1999). Genre memories and memory genres: A dialogical analysis of May 8, 1945 commemorations in the Federal Republic of Germany. American Sociological Review, 64(3), 381-402. https://doi-org.myaccess.library.utoronto.ca/10.2307/2657492.

Olson, W. (2019). Bison. In The Canadian Encyclopedia. Retrieved from https://www.thecanadianencyclopedia.ca/en/article/bison.

Parks Canada. (2018). Historic Sites and Monuments Board of Canada. History and culture. Retrieved from https://www.pc.gc.ca/en/culture/clmhc-hsmbc.

Parks Canada. (2018). Main criteria and guidelines. History and culture. Retrieved from https:// www.pc.gc.ca/en/culture/clmhc-hsmbc/ncp-pcn/evaluation.

Parks Canada. (2019). Framework for history and commemoration. National Historic Sites. Retrieved from https://www.pc.gc.ca/en/lhn-nhs/plan/cadre-framework.

Parks Canada. (2019). Introduction. National Historic Sites. Retrieved from https://www.pc.gc.ca/ en/lhn-nhs/introduction.

Parks Canada. (2019, March 30). Report on gatherings on Indigenous cultural heritage. Retrieved from https://heritagebc.ca/wp-content/uploads/2019/05/Report-on-Indigenous-Gatherings-on-Cultural-Heritage.pdf.

Parks Canada. (2020, July 31). Government of Canada recognizes Black history in Canada with four new historic designations. Government of Canada. Retrieved from https://www.canada. ca/en/parks-canada/news/2020/07/government-of-canada-recognizes-black-history-in-canada-with-four-new-historic-designations.html.

Pelletier, Y.Y.J. (2006). The politics of selection: The Historic Sites and Monuments Board of Canada and the imperial commemoration of Canadian history, 1919-1950. Journal of the Canadian Historical Association / Revue de la Société historique du Canada, 17(1), 125-150. https://doi. org/10.7202/016105ar.

Razack, S.H. (2002). Race, Space, and the Law. In S.H. Razack (Ed.), Race, space, and the law: Unmapping a white settler society (pp. 1-2). Between the Lines.

Regan, P. (2010). Unsettling the settler within: Indian residential schools, truth telling, and reconciliation in Canada. ProQuest Ebook Central. Retrieved from https://ebookcentral-proquest-com. myaccess.library.utoronto.ca/lib/utoronto/detail.action?docID=3412744.

Rice, B. \& Snyder, A. (2008). Reconciliation in the context of a settler society: Healing the legacy of colonialism in Canada. In Castellano, M. B., Archibald, L., \& DeGagné, M. (Eds.), From truth 
to reconciliation: Transforming the legacy of residential schools (pp. 43-63). Aboriginal Healing Foundation. http:/www.ahf.ca/downloads/from-truth-to-reconciliation-transforming-the-legacy-of-residential-schools.pdf.

Ricketts, S. (1996). Cultural selection and national identity: Establishing Historic Sites in a national framework, 1920-1939. The Public Historian, 18(3), 23-41. https://doi-org.myaccess. library.utoronto.ca/10.2307/3379211.

Shingwauk Residential Schools Centre. (n.d.). Reclaiming Shingwauk Hall. Retrieved from http:// reclaimingshingwaukhall.ca/.

Slotkin, R. (1985). The fatal environment: The myth of the frontier in the age of industrialization, 1800-1890. Yale University Press.

Smith, A. (2014). Native studies at the horizon of death: Theorizing ethnographic entrapment and settler self-reflexivity. In Simpson, A. \& Smith, A. (Eds.), Theorizing native studies (pp. 207-234). Duke University Press.

Stefanovich, O. (2020, September 1). Ottawa names two former residential schools as national historic sites. $C B C$ News. Retrieved from https://www.cbc.ca/news/politics/residential-school-system-national-historic-significance-1.5706136.

Strong-Boag, V. (2009). Experts on our own lives: Commemorating Canada at the beginning of the 21 st century. The Public Historian, 31(1), 46-68. https://doi-org.myaccess.library.utoronto. $\mathrm{ca} / 10.1525 / \mathrm{tph} .2009 .31 .1 .46$.

Sutherland, T. (2017). Archival Amnesty: In Search of Black American Transitional and Restorative Justice. Journal of Critical Library and Information Studies 1(2), 1-23. http://dx.doi. org/10.24242/jclis.v1i2.42.

Taylor, C.J. (1983). Some early problems of the Historic Sites and Monuments Board of Canada. The Canadian Historical Review, 64(1), 3-24. https://muse-jhu-edu.myaccess.library.utoronto.ca/ article/571468/pdf.

Trouillot, M. (2015) Silencing the Past: Power \& the Production of History. Beacon Press.

Truth and Reconciliation Commission. (2015). Honouring the Truth, Reconciling for the Future: Summary of the Final Report of the TRC. Winnipeg: Truth and Reconciliation Commission of Canada. Retrieved from http://www.trc.ca/assets/pdf/Honouring the Truth Reconciling for the Future July_23 2015.pdf.

Tuck, E. \& Yang, K. W. (2012) Decolonization Is Not a Metaphor. Decolonization, 1(1), 1-40. Retrieved from https://jps.library.utoronto.ca/index.php/des/article/view/18630. 